\title{
USING AGGREGATING DEVICES TO SAMPLE FISH RECRUITS AROUND DEEP SHIPWRECKS: EXPERIMENTS AND SUGGESTIONS
}

\section{Usando estruturas de agregação para amostrar recrutas de peixes ao redor de naufrágios profundos: experimentos e sugestões}

\author{
José Renato Mendes de Barros Correia ${ }^{1}$, Erandy Gomes da Silva², Carlos Augusto França Schettini ${ }^{3}$, \\ José Carlos Pacheco dos Santos ${ }^{4}$, Tiago Hilário Pedrosa Campello ${ }^{5}$, Maria Elisabeth de Araújo ${ }^{6}$ \\ ${ }^{1}$ Bolsista de doutorado Capes, Laboratório de Nécton (IMAT), Departamento de Oceanografia, \\ Universidade Federal de Pernambuco. E-mail: renato.bcorreia@gmail.com \\ ${ }^{2}$ Laboratório de Nécton (IMAT), Departamento de Oceanografia, Universidade Federal de Pernambuco. \\ E-mail: erandygomes13@gmail.com \\ ${ }^{3}$ Professor titular, Laboratório de Oceanografia Costeira e Estuarina (LOCostE), Instituto de Oceanografia, \\ Universidade Federal do Rio Grande. E-mail: guto.schettini@gmail.com \\ ${ }^{4}$ Professor adjunto, Laboratório de Operações Aquáticas e Aquicultura, Universidade Federal Rural de Pernambuco, \\ Unidade Acadêmica de Serra Talhada. E-mail: pachecodive@hotmail.com \\ ${ }^{5}$ Professor, Universidade Federal Rural de Pernambuco, Unidade Acadêmica de Serra Talhada. \\ E-mail: tiagohpcampello@gmail.com \\ ${ }^{6}$ Professora, Laboratório de Nécton (IMAT), Departamento de Oceanografia, \\ Universidade Federal de Pernambuco. E-mail: betharau08@gmail.com
}

\begin{abstract}
Fish aggregating devices (FAD) are an ancient fishery technique that benefits from the gregarious behavior of many species. They represent alternatives to usual census approach to study fish recruits. Based on this, we test two FAD models built for fish recruitment research, Standard monitoring unit for the recruitment of reef fishes (SMURF) and Artificial Reef Mooring (ARM) moored for the first time close to deep shipwrecks in Brazil Northeastern coast. We compared fish recruits' abundance sampled by both models at two depths, bottom and mid-water (6 meters from the bottom). SMURFs sampled seven times more fish recruits than ARM with no difference between depth. We discovered that SMURFs mooring tilted $24^{\circ}$ in mean with local marine currents. A long-term study with SMURFs tested immersion time influence in recruit's sampling, and explored recruit's abundance and standard length at two depth from the bottom. Increasing immersion time from 14-28 days did not influence recruit's abundance. Bottom and Mid-water SMURFs sampled equal recruit's number and fish sizes were significantly larger at the bottom. FADs, specially SMURFs, showed good tool to sample fish recruits in deeper shipwrecks,
\end{abstract}

Recebido em: 10/10/2019

Aprovado em: 08/06/2020

Publicado em: 30/08/2020 
however standardization of FAD deployment is indicated to maximize work time and security in unstable sea conditions.

Keywords: SMURF, ARM, artificial reefs, reef fish, fish recruitment.

\section{RESUMO}

Estruturas de agregação de peixes (FAD) são uma técnica antiga da pesca que se beneficia do comportamento gregário de muitas espécies. Representam alternativas à técnica comuns de senso visual para estudar recrutas dos peixes. Com base nisso, testamos dois modelos FADs construídos para pesquisa de recrutamento de peixes, unidade de padrão de monitoramento de recrutamento de peixes recifais (SMURF) e recifes artificiais ancorados (ARM) posicionados pela primeira vez perto de naufrágios profundos na costa nordeste do Brasil. Nós comparamos a abundância de recrutas de peixe amostrados por ambos os modelos em duas profundidades, fundo e meia-água (6 metros do fundo). SMURFs amostraram sete vezes mais recrutas de peixe do que ARMs sem diferença entre as profundidades. Descobrimos que os SMURFs inclinam $24^{\circ}$ em média com correntes marinhas locais. Um estudo a longo prazo com SMURFs testou a influência do tempo de imersão na amostragem de recrutas e explorou a abundância do recruta e o comprimento padrão em duas profundidades a partir do fundo. O aumento do tempo de imersão de 14-28 dias não influenciou a abundância de recrutas. SMURFs de fundo e meia-água amostraram números iguais de recrutas e tamanhos de peixes foram significativamente maiores nos localizados no fundo. FADs, especialmente SMURFs, mostraram boa ferramenta para amostrar recrutas de peixes em naufrágios mais profundos, no entanto a padronização da implementação do FAD é indicada para maximizar o tempo de trabalho e segurança em condições instáveis de mar.

Palavras-chave: SMURF, ARM, recifes artificiais, peixes recifais, recrutamento.

\section{INTRODUCTION}

Fish Aggregating Devices (FADs) are instruments used for centuries by artisanal fishermen to attract fish and facilitate your capture (National Research Council, 1988).

A historical review of these devices found that the earliest known use of FADs dates back to 200 AD in the Mediterranean, and that it has also been used for hundreds of years by traditional fishermen in Japan, Indonesia, Malaysia and the Philippines (Dempster \& Taquet, 2004) This fishery is known for names such as "kannizzati", "capcer" and "'cannizzi" in Mediterranean (Galea, 1961; Morales-Nin et al., 2000), and the FADs known as "tsuke" in Japan (Francois, 1991), "rumpon" in Indonesia and "unjang" in Malaysia (Bergstrom, 1983) and "payao" in Philippines (Murdy, 1980). Their constructions were (and still are) basically made by vegetal material such as trunks and trees, bamboo, palm leaves, cork, grass (Gooding \& Magnuson, 1967; National Research Council, 1988; Dempster \& Taquet, 2004).

This technique makes use of the behavior of many species that remain aggregated and seek shelter, protection, and places for reproduction or feeding (Soemarto, 1960; Gooding \& Magnuson, 1967; Hunter \& Mitchell, 1967), although the food is not necessarily obtained from fouling organisms in the FAD (Ibrahim et al., 1996). This characteristic of fish attraction to floating objects was called "thigmotropism" in fish (Ibrahim et al., 1996). 
The use of FADs on the mature fish ecology became common (Alevizon \& Gorham, 1989; Deudero et al., 1999), but to study fish early stages, FADs provided a much larger advance given the difficulty of capturing small individuals (Walsh, 1985). Schroeder (1987) used moored FADs for the first time in research focusing exclusively for young fish. Your system allowed select individuals' sizes, as well as facilitate your collection.

The "Schroeder's basket", as it was called, was used to characterize the different young fish communities at different depths (Leis et al., 2002). Ammann (2004) developed the Standard Monitoring Units for Reef Fishes (SMURFs) that resembled the Schroeder's basket, but with your interior composed of randomly folded nets, enabling greater complexity than the previous FAD model. The SMURF model followed being used from temperate to tropical environments (for example Caselle \& Warner, 1996; Ben-David \& Kritzer, 2005; Caselle et al., 2010). Also, with the purpose of studying the recruitment of coral reef fish, were developed versions of the SMURFs fixed to the bottom and composed by fragments of corals and/or rocks, known as "benthic collectors" (Steele et al., 2002; Valles et al., 2006).

Differences in post recruitment success of fish may be due to own species characteristics, and also due to geographic location, water mass displacement carrying eggs and larvae and inherent characteristics of the species (Shulman et al., 1983; Shulman, 1985; Shulman \& Ogden, 1987). Those factors determine the size of adult populations (Jones, 1990; Lewis, 1997).

On the exposed, our goals were to optimize FAD deployment at deeper depths on open waters and to compile published data around fish recruitment using FADs. We have done, also, an experimental (in loco) designs to identify 1) the efficiency of different FADs models to sample fish recruits, 2) the abundance of fish recruits and recruit sizes sampled by the most efficient FAD model between two depths, 3) the influence of FAD immersion time in recruits sampling and 4) the influence of ocean currents hydrodynamics on the FADs moorings.

\section{MATERIALS AND METHODS}

\section{Study area}

The study took place in shipwrecks in the coastal area from Pernambuco State (Northeastern Brazil), located between $9-13 \mathrm{~km}$ away from the port of Recife city (Figure 1). The shipwreck Pirapama $\left(8^{\circ} 3^{\prime} 23.00^{\prime \prime} \mathrm{S}\right.$ and $\left.34^{\circ} 46^{\prime} 58.00^{\prime \prime} \mathrm{W}\right)$, sunk in 1889 , incidentally, measures $60 \mathrm{~m}$ total length, is located $21 \mathrm{~m}$ depth and is oriented with the bow facing Southwest (Santos et al., 2010) (Figure 1, inset). The shipwrecks Taurus and Virgo (8 $4^{\prime} 11.58^{\prime \prime}$ $\mathrm{S}$ and $\left.34^{\circ} 45^{\prime} 11.76^{\prime \prime} \mathrm{W}\right)$ with approximately $25 \mathrm{~m}$ total length were sunk deliberately to 25 $\mathrm{m}$ depth, in 2006 (Santos et al., 2008) and 2017 (Correia et al., 2018), respectively. They form a complex of artificial reefs, with the wrecks separated each other by $9 \mathrm{~m}$. This distance was measured in situ using measuring tape in December 2017. In December 2018, a bathymetric model using single-beam echo sounder data was built and confirmed this measurement (Correia et al., in preparation). The bow of the Taurus faces East-Southeast (E-SE), and the bow of the Virgo faces South-Southeast (S-SE) (Figure 1, inset).

Regional tides are semi-diurnal, ranging from 1.5 to $3 \mathrm{~m}$ at neap and spring periods, respectively. Shelf currents are mainly driven by winds. Wind is predominantly easterly, being strongest between August to October, when the currents are strongest and northwards. Between January and March, the wind relaxes, and the shelf currents are 
sluggish southwards. Shelf waters are dominated by Tropical Water, with salinity $>36.5$ psu and temperature $>26^{\circ} \mathrm{C}$ (Schettini et al., 2017).

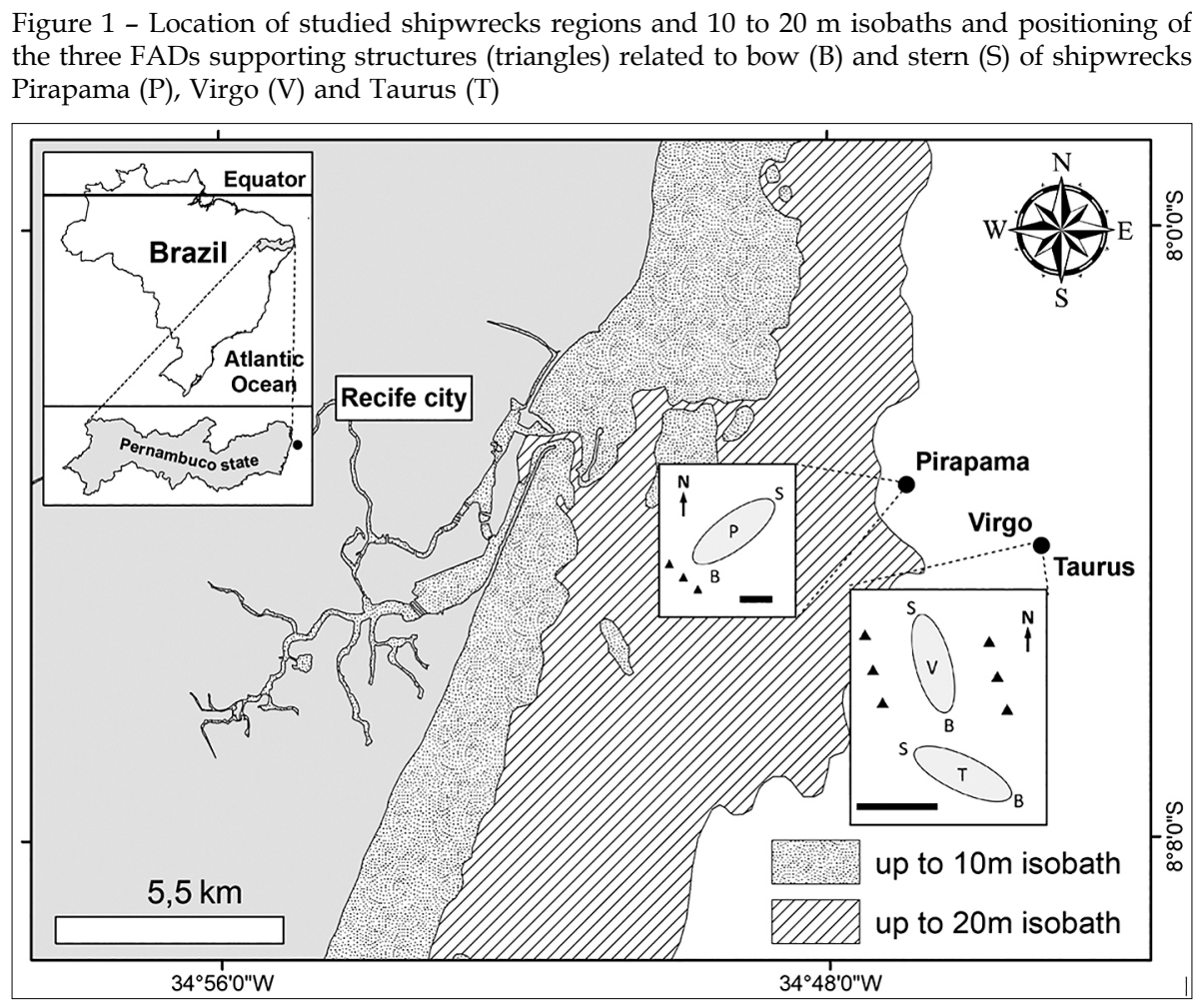

\section{Compilation of fish recruitment researches using FAD}

To access published information on the use of FADs in the study of fish recruitment we conducted surveys in online databases. These surveys were gathered in spreadsheets to visualize the following information: FADs models, dimensions of FADs, volume of FADs (informed or calculated by dimensions), depth of study area, maximum and minimum sampling depths with the FAD and the diving method used in the samplings.

\section{FAD structures and mooring set-ups}

This research was conducted using two FAD models: ARM (Artificial Reef Mooring) and SMURF. ARM model was modified from Schroeder (1987). It was successfully used by Leis et al. (2002) and its name created by Paiva et al. (2015). The structure of the ARMs was composed of a spiral cylindrical frame $(0.6 \mathrm{~m}$ length $\times 0.20 \mathrm{~m}$ diameter $)$ of black fencing plastic net with mesh size of $2 \times 2 \mathrm{~cm}$ and stainless-steel snap-clips tied to frame (Figure 2B and 2C). SMURFs model was modified from Ammann (2004). It was composed of a closed cylindrical frame $(0.8 \mathrm{~m}$ length $\times 0.35 \mathrm{~m}$ diameter $)$ of black plastic fencing net with mesh size of $2 \times 2 \mathrm{~cm}$ and filled with a, randomly folded, piece of $9.0 \times 1.2 \mathrm{~m}$ of a malleable and orange plastic net with mesh size $5 \times 7 \mathrm{~cm}$ (Figure 2A and 2D) with a neutral buoyancy.

Our SMURFs model were constructed with a spinal cord made of a $20 \mathrm{~mm}$ PVC pipe where stainless-steel snap-clips were tied, to maintain format and volume of the frame against local marine currents.

In the field, the ARMs and SMURFs were moored with a structure composed of anchor, rope and mid-water buoy to ensure that they remained mid-water suspended at a 
maximum of 6 meters above the sandy bottoms (Figure 2C and 2D, respectively). Two SMURFs were fastened per mooring, being one on the bottom and one 6 meters above. Three moorings were positioned near the shipwrecks: the bow of the wreck Pirapama, port side and starboard of the wreck Virgo. Depending on winds, Pernambuco coastal waters can change from calm and clear to turbulent and turbid. To prevent drag and loss of FAD's structures, the moorings were connected by $10 \mathrm{~m}$ coated steel cables attached to the anchors, separated 10 meters from each other and 10 meters from shipwreck.

Figure 2 - FADs models' schematic drawing. (A) SMURF showing the spinal cord (circled C) made of $20 \mathrm{~mm}$ PVC pipe and the two stainless steel snap-clips (circled S) used to clip in mooring rope. (B) ARM showing two stainless steel snap-clips (circled S) also used to clip in mooring rope. (C) ARMs and (D) SMURFs mooring (anchor, rope and mid-water buoys) used in experiments of Phase 1, comparison between the ARMs and SMURFs from Mid-water and Bottom, and Phase 2 immersion time experiment

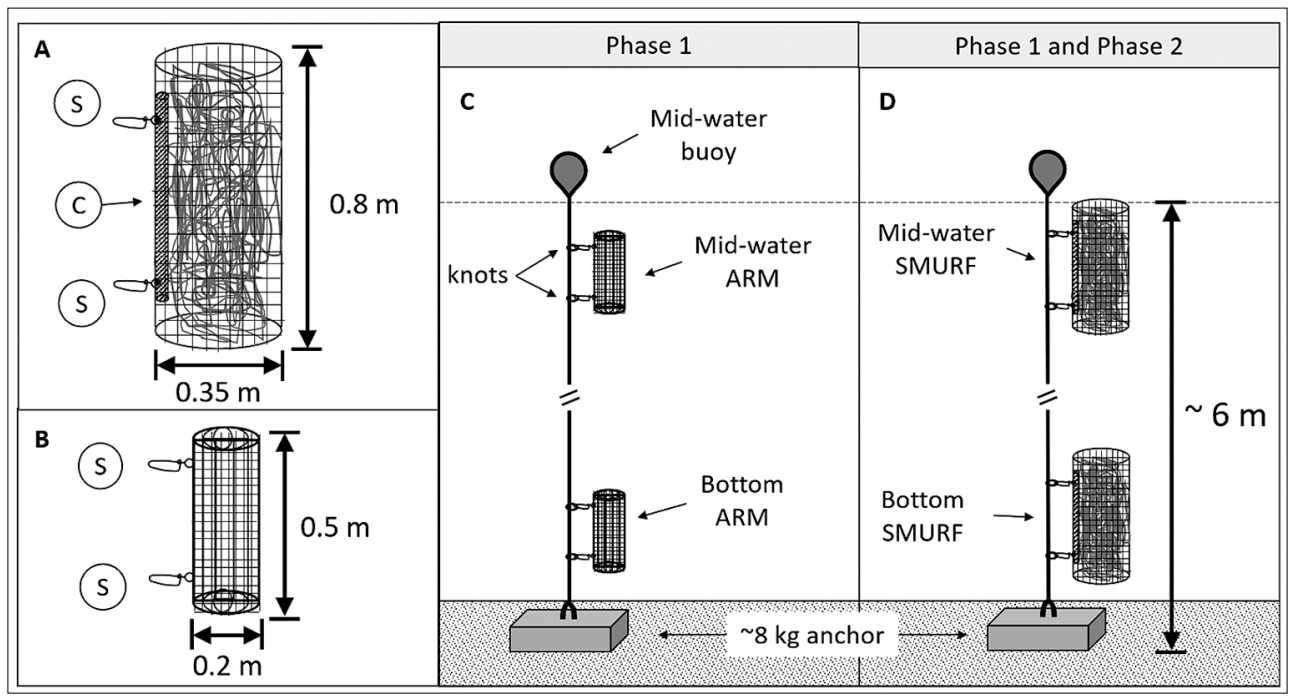

To deploy the FADs on the moorings close to the shipwrecks, FADs were packed into six-FADs-group that was clipped to an auxiliary cable, positioned at the side of support boat (Figure 3). With an attached diving ballast aid, the group sunk until the connection of the auxiliary cable to the main cable (where which support boat was tied to shipwreck) 5 $\mathrm{m}$ below surface, and a diving security stop zone as well. There, the set of FADs waited until three divers where in the water. Then divers conducted the arrange by the main cable to shipwreck deck. Arriving at wreck deck, six-FADs-group was unclipped from main cable, divided two FADs per diver and all divers swam to the same mooring position to proceed FADs collection and changing (Figure 4A). After FADs collection divers returned with a collected six-FADs-group trough the main cable (Figure 4B), executed a security stop at $5 \mathrm{~m}$, switched to auxiliary cable and proceed to support boat.

This methodology was used to increase security of divers and to prevent drifting from the boat due sudden wind driven superficial currents formed by climatic instability in the region.

Each diving operation took about 25 to $35 \mathrm{~min}$ ( $25 \mathrm{~min}$ in calm days with no drift currents and 30-35 min in rough days with more winds, drift currents and higher waves) from the begging of divers descend until return to surface. Each six-FADs-group took about 15 min to be collect and the remaining time spent on descend, swimming to moorings, returning to main cable and to surface. All divings were done with regular air in the tanks 
and with aid of dive computers in a multilevel diving (bottom FADs were collected first and then Mid-water ones were collected).

Figure 3 - FADs deployment in water. (1) A six-FADs-group clipped to an auxiliary cable, positioned at the side of support boat, and then (2) sunk until $5 \mathrm{~m}$. (3) six-FADs-group being conduct by the main cable, which connected support boat to shipwreck deck. FADs lifting occurred in reverse order (3) to (2) to (1). *SMURF used for example. ARMs deployment occurred similarly. Figure inset (A): A six-FADs-group (arranged 2 by 2 ) and tied in a (C) 1-ton carabiner and a (B) $3 \mathrm{~kg}$ diving ballast

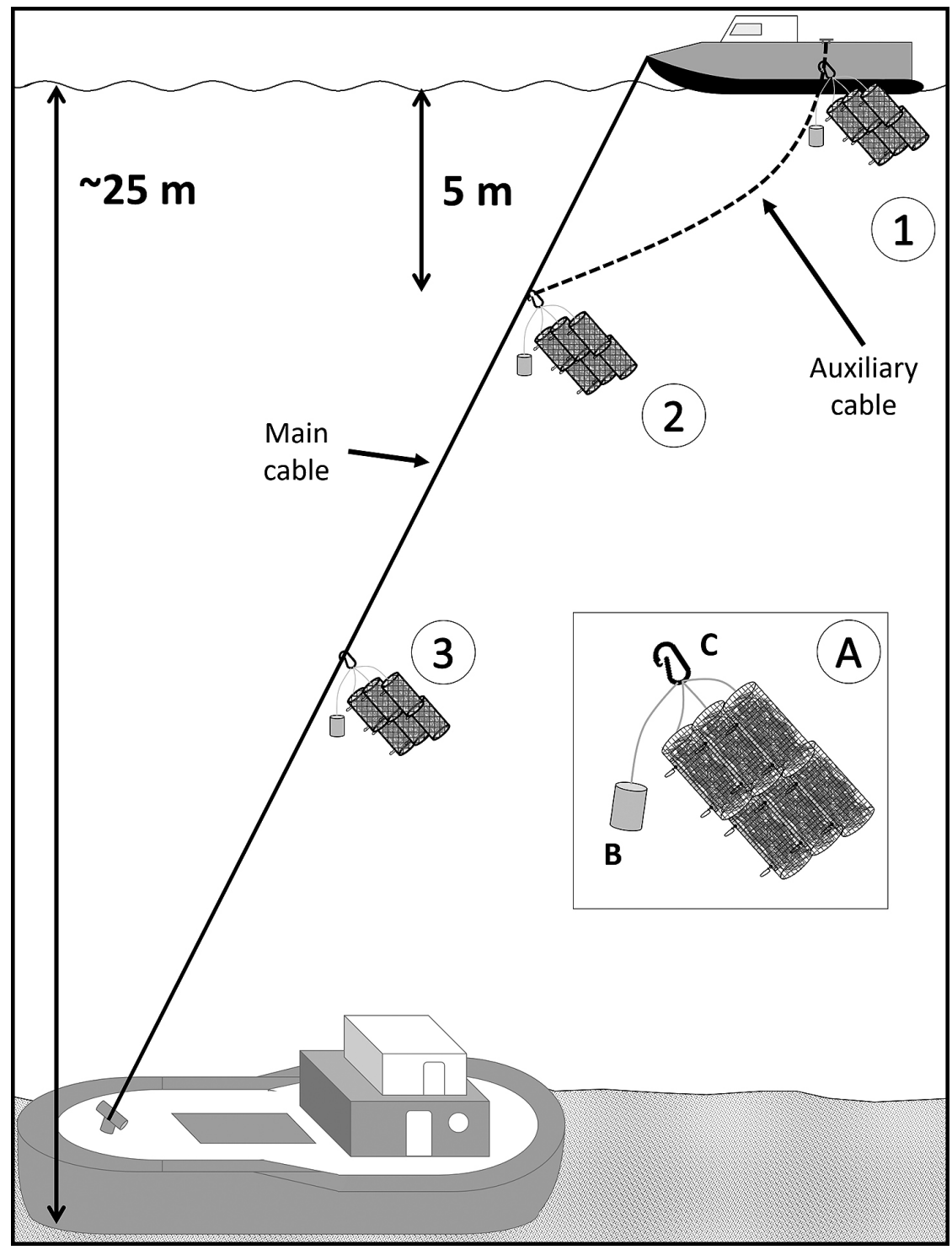

Figure 4 - Divers involving and collecting SMURFs with cylindrical net with $5 \mathrm{~mm}$ of mesh size (A). Divers returning to surface by the main cable with collected six-FADs-group (B) 
Pilot experiment: To test the handling feasibility, durability of structures and ability to sample specimens at deeper regions, a pilot test was run with the FAD model SMURF. This run also served to deploy all the moorings used in subsequent experiments. Three moorings were positioned in three regions near the shipwrecks: bow of the wreck Pirapama, port side and starboard of the shipwreck complex Taurus-Virgo (Figure 1, inset triangles), 10 meters separated each other. Immersion intervals ranged 14 to 109 days, from September 2016 to March 2017. SMURFs were collected individually with a cylindrical net with $5 \mathrm{~mm}$ of mesh size and specimens were counted, measured and preserved in alcohol $70 \%$.

\section{FADs model comparison - Phase 1}

In this first phase, the objective was to compare the efficiency to sample the recruits between SMURFs and ARMs. At sea, the support structures mounted for pilot experiments were used to position two SMURFs (Figure 2B) and two ARMs (Figure 2C). Each model of FAD was positioned: one in bottom and other in $6 \mathrm{~m}$ from the bottom in the same areas of pilot study. The immersion time until the collection ranged between 13 and 32 days and occurred between the months of March and June 2017. SMURFs and ARMs were collected individually with a cylindrical net with $5 \mathrm{~mm}$ of mesh size and specimens were counted, measured and preserved in alcohol $70 \%$.

\section{Long-term experiments - Phase 2}

In Phase 2, the objective was to perform long-term study in the Taurus-Virgo shipwreck complex to identify the relation between SMURF immersion time and recruit abundance per SMURF. We also identify the influences of depth (bottom and mid-water, see Figure 2) over fish recruit abundance and sizes. The immersion time until the collection ranged between 14 and 28 days and occurred from October 2017 to February 2019. The SMURFs collections and specimen's processing were exactly the same as Phase 1.

\section{Hydrodynamic measurements and flow effects on the SMURFs}

The FADs structures, especially SMURFs, produced drag and the mooring tilted with currents. To investigate the effects of the flow on the mooring and its efficiency regarding the level of each trap, we perform an experiment to measure how the mooring tilt with currents (Figure 5). A SMURF mooring was set up in a diving pool with $\sim 5.5 \mathrm{~m}$ at the deepest part, and $\sim 12 \mathrm{~m}$ wide (we tested only SMURFs because they produce more drag than ARMs). The mooring was on a sled, where there was also an electromagnetic current meter (EMCM) recording at $1 \mathrm{~s}$ interval, at $\sim 0.5 \mathrm{~m}$ above the bed, a protractor aligned with the mooring rope, and an underwater video recording camera. The sled was trawled across the pool at nearly constant speed each time, in a total of 8 trawls. The mean angle and mean velocity were averaged for each trawl. The data was plotted on a polynomial regression.

To assess the temporal efficiency, we use a data set of currents recorded at $25 \mathrm{~m}$ deep nearly $18 \mathrm{~km}$ south from the wrecks. These data were recorded with an acoustic Doppler current profiler (by Nortek A/S model Aquadopp Current Profiler of 1,000 kHz) at hourly intervals between 2 June and 19 October 2011, and with $1 \mathrm{~m}$ of vertical resolution (Schettini et al., 2018). The lowest 5 beans were depth-averaged to give the frequency of current velocities at the bottom layer where the SMURFs were positioned. Bottom currents 
frequency were related with tilt angle polynomial equation to find mooring tilt angle frequency with local currents.

\section{DATA ANALYSIS}

We analyzed the data from Phase 1 experiments (FADs model comparison) considering the abundance of recruits per FAD. Although data from Phase 1 passed in Levene's test $(p=0.117)$ they were not normal in Kolmogorov Smirnov's test $(p<0.05)$ so we compared data through Multifactorial GLM analysis to test FAD models, Depth and interactions $(\alpha=0.05)$. Phase 2 data, recruits sampling and recruits' sizes per depth, were not normal in Kolmogorov Smirnov's test $(p<0.05)$, so we tested then through Mann-Whitney Rank Sum Test $(\alpha=0.05)$. We performed a linear regression of the $\log 10$ transformed recruit samples per FAD and immersion time to investigate if increasing FAD time in water would affect recruit sampling. All statistical analysis and graphs were created in Sigmaplot 11 (Systat Sofware).
Figure 5 - SMURF buoyancy system tilt angle (a) experiments on diving pool. SMURF's set up mounted on non-magnetic frame constructed with a wooden tray $(\mathrm{T})$, protractor $(\mathrm{P})$ and sticks (S) holding electromagnetic current meter (EMCM) fixed by non-magnetic metal clamps (MC) and a video camera (C). Diving ballast (DB) maintained frame on pool bottom and a rope (R) was used to push the frame and create a flow

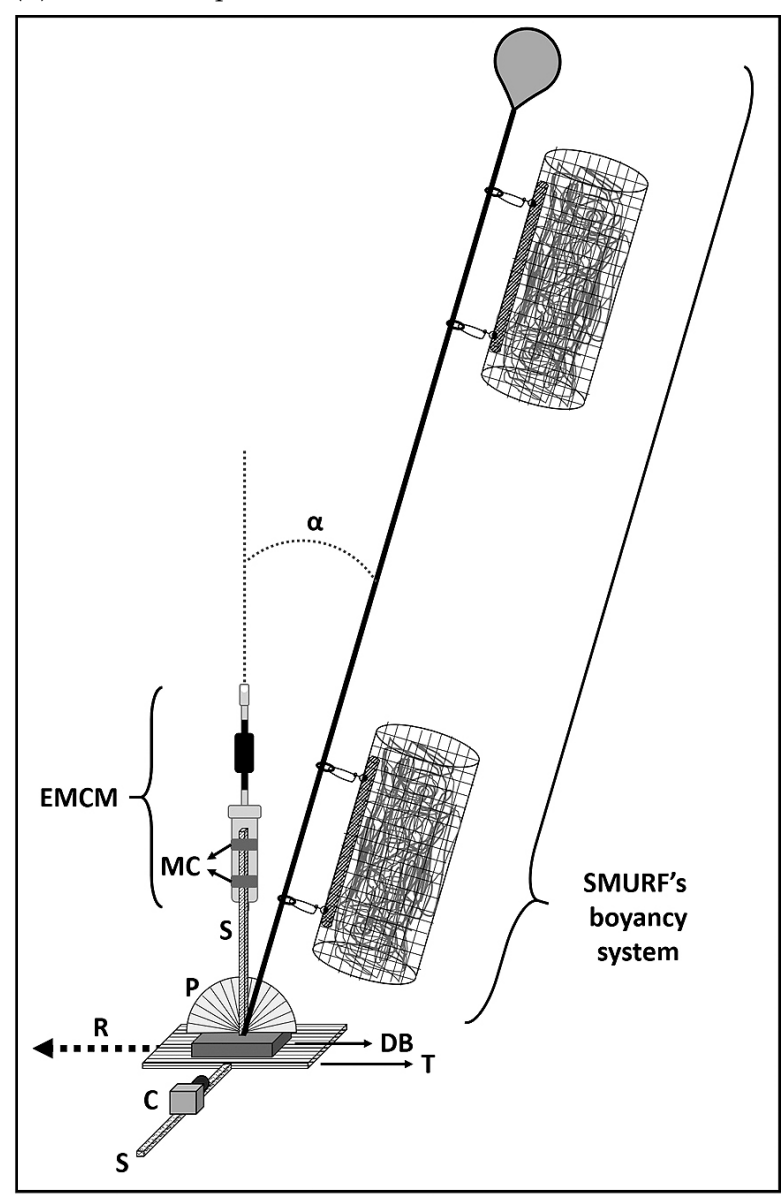

\section{RESULTS}

\section{Compilation of fish recruitment researches using FAD}

Comparing the 31 studies that collected fish recruits with FAD's methods (Table I), approximately $71 \%$ used SMURF, $19 \%$ Benthic collector, $10 \%$ ARM, and $39 \%$ did not give the information about the FADs used. Only 10\% installed FADs at depths below the basic dive limits of $18 \mathrm{~m}$. Concerning the dive method used in the FAD collections, only 10 of them reported it, and $60 \%$ of these studies using Scuba.

\section{FADs model comparison - Phase 1}

The FAD model SMURF sampled significantly more recruits (119) compared to ARM which sampled in total only 9 individuals. There were no differences in abundances of recruits sampled at the depths tested for both FADs and no interaction between model and depth (Table II, Figure 6). 
Table I - Characteristics of devices and studied areas, and device collection methods used in fish recruitment research with FAD. FADs models (ARM, Benthic collector and SMURF) were used to devices with construction similar to Schroeder (1987), Valles et al. (2006) and Ammann (2004), respectively. Symbols legends: (?) unclear information; (-) nonexistent information. The complete reference is in literature cited

\begin{tabular}{|c|c|c|c|c|c|c|c|c|}
\hline \multirow[t]{2}{*}{ Study } & \multirow[t]{2}{*}{$\begin{array}{c}\text { FAD } \\
\text { model }^{\mathbf{a}}\end{array}$} & \multirow[t]{2}{*}{$\begin{array}{l}\text { Radius } \\
\text { (m) }\end{array}$} & \multirow[t]{2}{*}{$\begin{array}{l}\text { Height } \\
\text { (m) }\end{array}$} & \multirow{2}{*}{$\begin{array}{c}\text { Informed or } \\
\text { calculated } \\
\text { FAD volume } \\
\left(\mathbf{m}^{3}\right)\end{array}$} & \multirow[t]{2}{*}{$\begin{array}{c}\text { Area } \\
\text { depth } \\
(\mathrm{m})\end{array}$} & \multicolumn{2}{|c|}{$\begin{array}{l}\text { Sampling } \\
\text { depth }(\mathrm{m})\end{array}$} & \multirow[t]{2}{*}{$\begin{array}{l}\text { Diving } \\
\text { method }\end{array}$} \\
\hline & & & & & & Min & Max & \\
\hline Schroeder, 1987 & $\mathrm{ARM}$ & 0.10 & 0.30 & 0.01 & 10 & 3 & 6 & - \\
\hline Leis et al., 2002 & ARM & 0.10 & 0.30 & 0.01 & 15 & 7 & 13 & - \\
\hline Paiva et al., 2015 & ARM & 0.10 & 0.30 & 0.01 & 6 to 9 & 2 & 7 & - \\
\hline Steele et al., 2002 & $\begin{array}{l}\text { Benthic } \\
\text { collector }\end{array}$ & - & - & 0.49 & 7 to 15 & 7 & 15 & - \\
\hline Valles et al., 2006 & $\begin{array}{l}\text { Benthic } \\
\text { collector }\end{array}$ & 0.30 & 0.13 & 0.04 & 7 to 12 & 7 & 12 & Scuba diving \\
\hline Valles et al., 2008 & $\begin{array}{l}\text { Benthic } \\
\text { collector }\end{array}$ & 0.30 & 0.13 & 0.04 & $\sim 8.7$ & $\sim 8.7$ & $\sim 8.7$ & $?$ \\
\hline Valles et al., 2009 & $\begin{array}{l}\text { Benthic } \\
\text { collector }\end{array}$ & 0.30 & 0.13 & 0.04 & - & - & - & $?$ \\
\hline Arney et al., 2017 & $\begin{array}{l}\text { Benthic } \\
\text { collector }\end{array}$ & - & - & 0.03 & 20 & 0 & 20 & Scuba diving \\
\hline Miller et al., 2014 & $\begin{array}{l}\text { Benthic } \\
\text { collector }\end{array}$ & 0.30 & 0.13 & 0.04 & 3 to 20 & 3 & 20 & Scuba diving \\
\hline Steele et al., 2002 & SMURF & 0.15 & 0.90 & 0.06 & 7 to 30 & 5 & 5 & - \\
\hline Ammann, 2004 & SMURF & 0.18 & 1.00 & 0.10 & 18 to 19 & 1 & 19 & $\begin{array}{c}\text { Snorkelling } \\
\text { and Scuba } \\
\text { diving }\end{array}$ \\
\hline Luzier \& Wilson Jr, 2004 & SMURF & - & - & - & - & - & - & - \\
\hline Ben-David \& Kritzer, 2005 & SMURF & - & - & - & 2 to 5 & $?$ & $?$ & - \\
\hline Selkoe et al., 2006 & SMURF & - & - & - & - & - & - & - \\
\hline Stephens et al., 2006 & SMURF & 0.18 & 1.00 & 0.10 & - & - & - & - \\
\hline Siddon et al., 2008 & SMURF & - & - & - & 6 to 8 & 1 & 7 & Scuba diving \\
\hline White \& Caselle, 2008 & SMURF & - & - & - & 15 & 3 & 3 & - \\
\hline Shima \& Swearer, 2009 & SMURF & 0.18 & 1.00 & 0.10 & $\sim 6$ & $?$ & 4 & - \\
\hline Caselle et al., 2010 & SMURF & 0.18 & 1.00 & 0.10 & 4.5 & 1.5 & 1.5 & - \\
\hline Tavertti et al., 2009 & SMURF & 0.18 & 1.00 & 0.10 & 4.5 & 1.5 & 1.5 & - \\
\hline Crean et al., 2010 & SMURF & - & - & - & - & - & - & $?$ \\
\hline Kohn \& Clements, 2011 & SMURF & - & - & - & - & - & - & - \\
\hline Lotterhos \& Markel, 2012 & SMURF & $0.18^{\mathrm{b}}$ & $1.00^{\mathrm{b}}$ & $0.10^{\mathrm{b}}$ & 6 to $18^{\mathrm{b}}$ & 1 & 2 & - \\
\hline Shima et al., 2012 & SMURF & - & - & - & 3 to 6 & 1 & 4 & - \\
\hline Jones et al., 2013 & SMURF & - & - & - & - & - & - & $?$ \\
\hline Morton \& Shima, 2013 & SMURF & - & - & - & 4 to 6 & 2 & 4 & Scuba diving \\
\hline Jones \& Mulligan, 2014 & SMURF & - & - & - & 12 & 1 & 1 & Snorkelling \\
\hline Haggarty et al., 2017 & SMURF & 0.18 & 1.00 & 0.10 & 6 to 18 & $1^{\mathrm{c}}$ & $2^{c}$ & - \\
\hline Ottman et al., 2016; 2018; 2019 & SMURF & 0.15 & 1.00 & 0.07 & 15 & 1 & 1 & Snorkelling \\
\hline Klein et al., 2018 & SMURF & 0.18 & 1.00 & 0.10 & 12 to 14 & 1 & 14 & Scuba diving \\
\hline Baetscher et al., 2019 & SMURF & - & - & - & - & - & - & Scuba diving \\
\hline
\end{tabular}

amodels names given after analysis of device construction inside study methodology

bobtained in Haggarty et al. (2017)

cobtained in Lotterhos \& Markel (2012) 
Figure 6 - Mean abundance (+standard deviation) of recruits caught with FADs modelsSMURF and ARM at Mid-water and Bottom depths. No recruits were sampled by mid-water ARMs

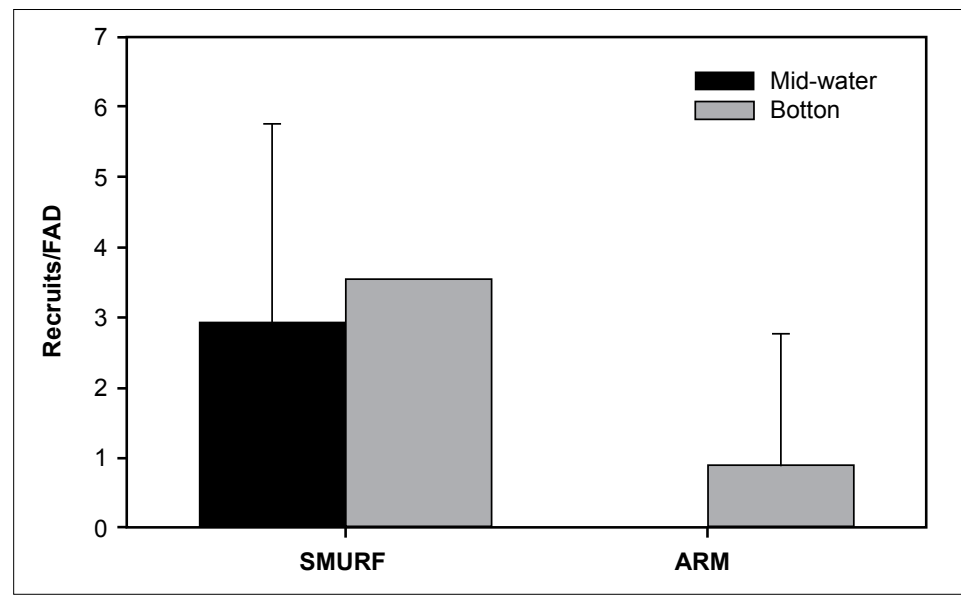

Table II - Multifactorial GLM test of FAD models and depths of deployment and interactions

\begin{tabular}{lcrrrr}
\hline Source of Variation & DF & \multicolumn{1}{c}{ SS } & MS & F & \multicolumn{1}{c}{$\boldsymbol{P}$} \\
\hline FAD MODEL & 1 & 76.494 & 76.494 & 17.155 & $<0.001$ \\
Depth & 1 & 5.941 & 5.941 & 1.332 & 0.256 \\
FAD model x Depth & 1 & 0.161 & 0.161 & 0.036 & 0.850 \\
Residual & 36 & 160.527 & 4.459 & & \\
Total & 39 & 242.775 & 6.225 & & \\
\hline
\end{tabular}

\section{Long-term experiments - Phase 2}

Immersion time influence and abundance and sizes of recruits sampled by SMURFs

There was no relation between immersion time of SMURFs and the number of recruits sampled per SMURFs, despite the slight positive angle in linear regression of both depths data (Figure 7).

Within Phase 2, using only SMURFs, 699 specimens were sampled, 464 on mid-water and 233 on Bottom ones. The Bottom and Mid-water sampled statistically equal numbers of fish recruits per FAD (Mann-Whitney's Test, $\mathrm{U}=2652.5, p=0.299$ ) with medians of 2.0 and 3.0, respectively (Figure 8A). Recruits sizes were bigger at the Bottom compared to Mid-water ones (Mann-Whitney's Test, $U=29583,5, p<0.001$ ). Recruits sampled had total lengths median of $2.5 \mathrm{~cm}$ on the bottom and $1.9 \mathrm{~cm}$ on Mid-water (Figure 8B), with variation between 0.8 and $6.1 \mathrm{~cm}$. All individuals were newly settlers and young juveniles, except for a couple of individuals that were adults from a small species.

Hydrodynamic measurements and flow effects on the SMURFs

The relationship of the tilt angle to the velocity can be described by tilt angle $=a^{*}$ velocity ${ }^{2}$ $+b^{*}$ velocity $+c\left(a=-282.7, b=265.1\right.$ and $c=-8.76 \times 10^{-6}$, with $\left.r^{2}=0.93\right)$ (Figure 9A). The Figure $9 \mathrm{~B}$ shows the accumulative frequency of current velocity, from $\sim 3,800$ temporal samples. The mean current during this period was $0.11 \mathrm{~m} / \mathrm{s}$, and the $50 \%$ and $90 \%$ percentiles were 0.08 and $0.19 \mathrm{~m} / \mathrm{s}$, respectively. With these flow conditions, the mean tilt angle was $24^{\circ}$, and at $90 \%$ of the time the tilt angle was $<40^{\circ}$ (Figure $9 \mathrm{C}$ ). Considering the planned height above the bed of $6 \mathrm{~m}$, the mean height predicted for local currents was $5.5 \mathrm{~m}$, and higher than minimum height of $4,5 \mathrm{~m}$ on $90 \%$ of the time obtained with the predictions. 


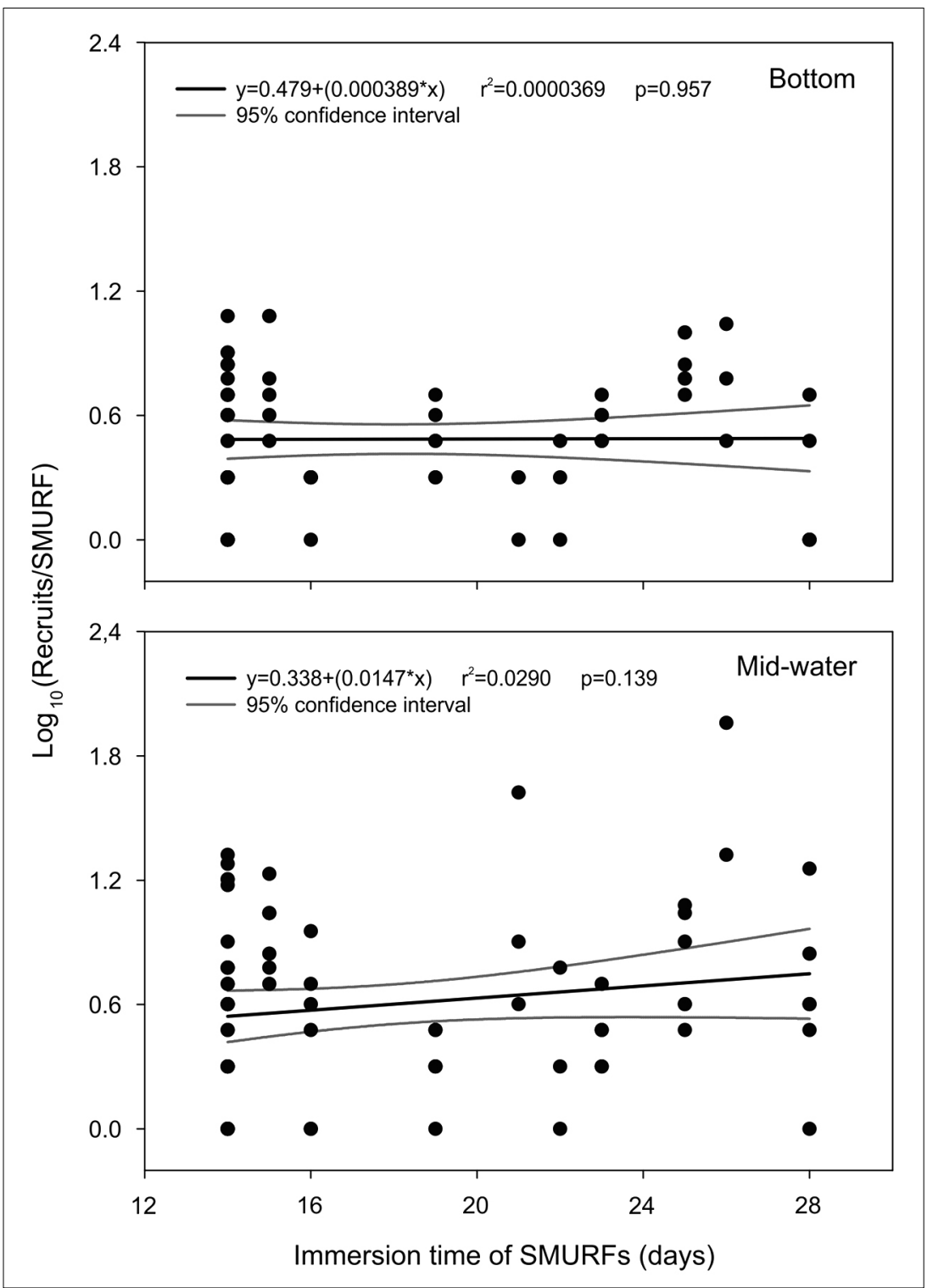

Figure $7-\log _{10}$ transformed of recruits catches per SMURF as a function of immersion time of Bottom and Mid-water SMURFs

Figure 8 - Boxplot of Recruits abundance per SMURF and Standard lengths at two depth in water column. Boxplot elements: percentiles, median and mean are described in the plot

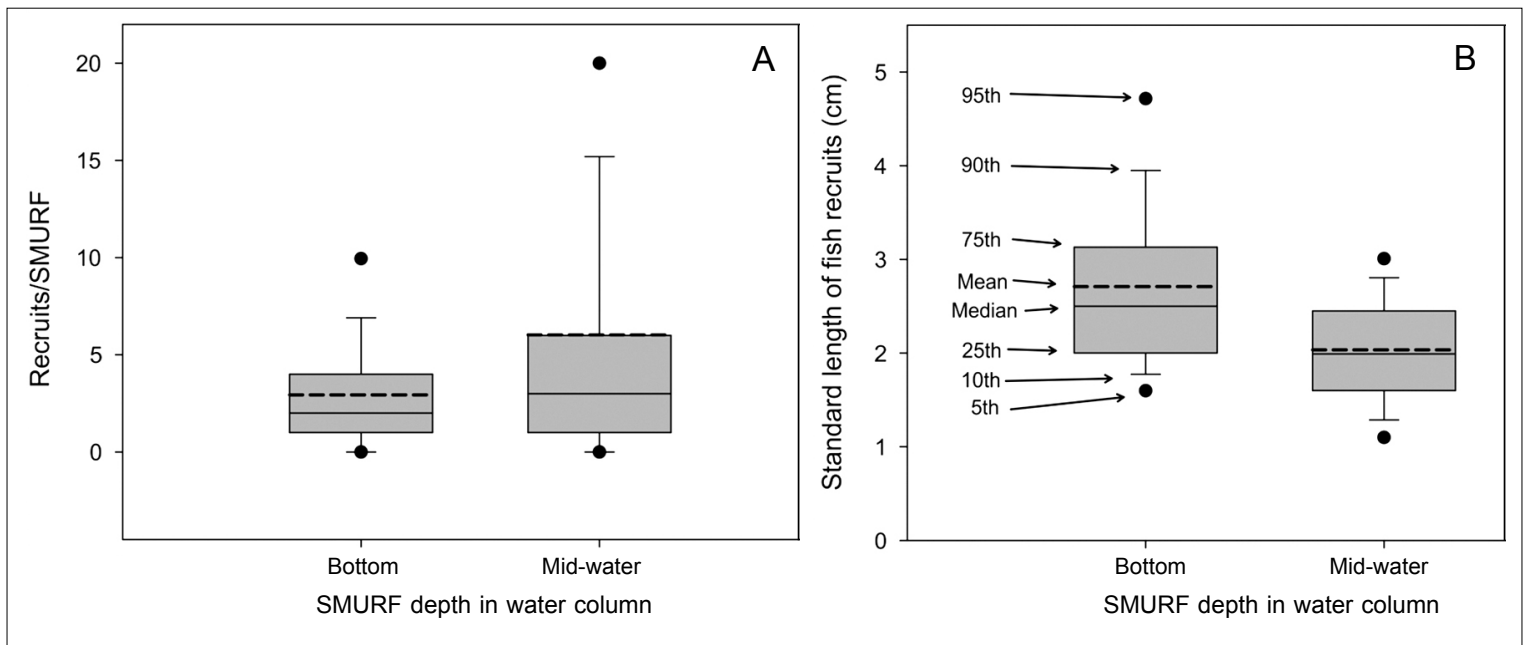


Figure 9 - Relationship of the tilt angle (a) of SMURF mooring structure to the current velocities. Regression obtained with SMURFs trawls experiments in a diving pool (A). Accumulative frequency of current velocities (measured by ADCP) for Recife city coast between 2 June and 19 October $2011^{*}$ (B). SMURF tilt angle predictions for the local current velocities $(\mathrm{C}) .{ }^{*}$ Schettini (unpublished data)

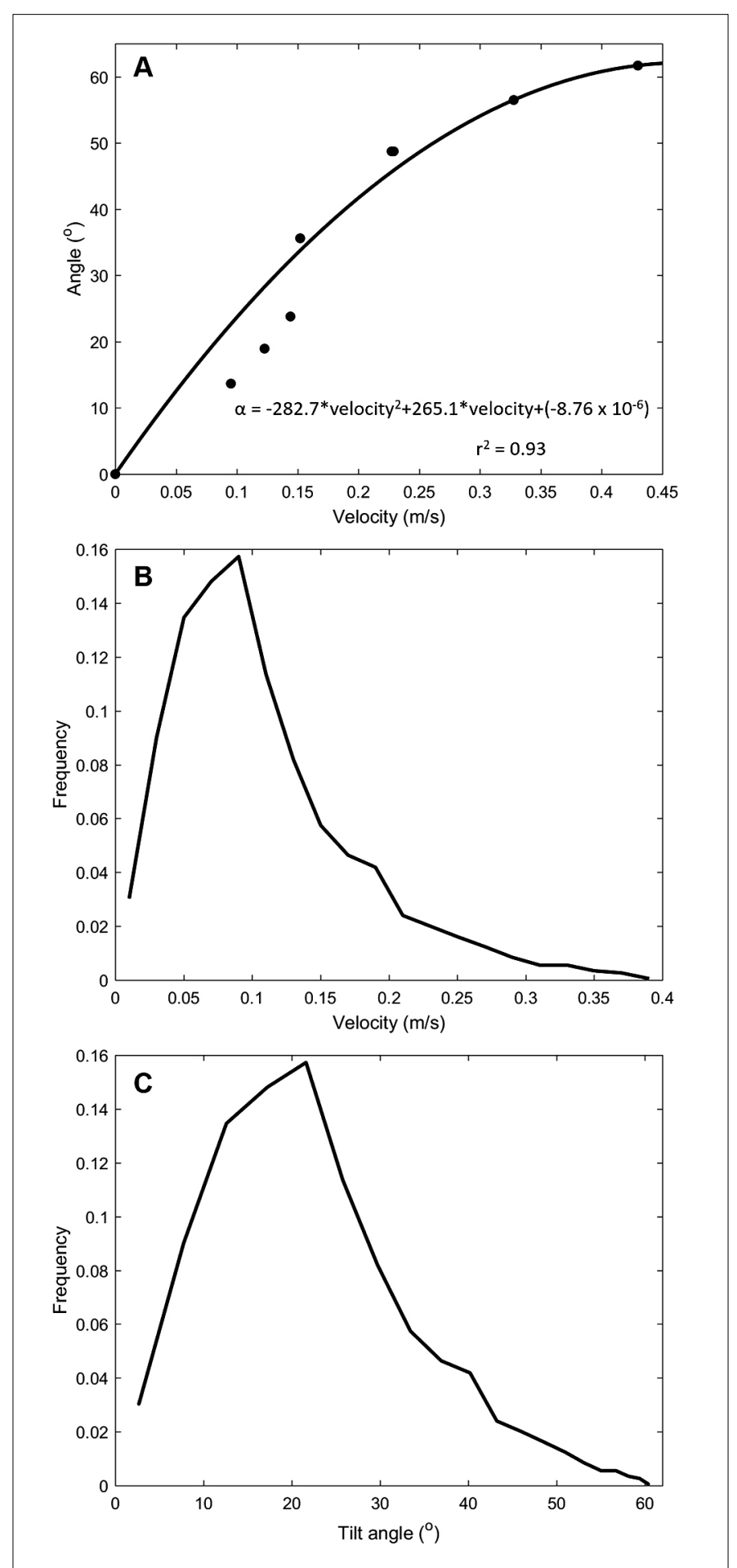




\section{DISCUSSION}

Experiment deployment at sea more specifically in open sea, require some level of skills both out of water and especially when there is need to enter the water. In this way, information about the method used for activities within the water is of essential value to clarify about the challenges that future researchers may face. Therefore, it is reckless when $70 \%$ of the studies surveyed do not make it clear about the method used to perform the experiments in the field. This represents an evident technical scientific gap. The information about dive method used is important, especially when sites sampled have great depths where a free dive does not reach. In the present study, for the first time, experiments with aggregation of recruits were implemented at depths below $20 \mathrm{~m}$, with implied extra caution for the researchers and the experiments (harder to access).

Among all FADs studies, ARM model were the least used despite its simple and inexpensive construction and rapid implementation in water, compared to benthic collectors that were composed of more complex constructions, take more time to implement in water (Klein, 2016) and require the use of anesthetics before involvement with the collection net (Vallès et al., 2006). SMURFs models were the most used among the 31 studies compiled. Its construction despite being simple and compared to the ARMs, aggregates the structural complexity found in the benthic collectors. Compared to SMURFs, Benthic collectors apparently were more effective sampling fish young stages, but the SMURF model sampled more the recruits (Klein, 2016).

The low efficiency of ARM model, compared to the SMURF, was unexpected, since several studies with ARM achieved relatively high recruits' catches (Schroeder, 1987; Leis et al., 2002; Paiva et al., 2015). These studies used sampling intervals smaller than the present study: 4 to 10 days (Schroeder, 1987), 2 days (Leis et al., 2002) and 7 days (Paiva et al., 2015), in addition to different positioning arrays and abundance calculations. Leis et al. (2002) computes the sample mean just for the FADs in which individuals of were found, while Schroeder (1987) calculates the abundance in recruits/FAD/day. On the other hand, authors like Paiva et al. (2015) do not report catches by FADs, just the total number of individuals per species per treatments. Our study registered a sample mean of 0.02 recruits / ARM/ day ( $\mathrm{n}=19$, [data not shown]), well below the minimum number found by Schroeder (1987), which was 0.21 recruits/ARM/day $(n=160)$ in a coral reefs environment, which was similar to the sample mean of SMURFs model in our study, 0.2 recruits/SMURF/day $(n=21)$. Despite the varied sampling times in this study, between 13 and 32 days, both (SMURFs and ARMs) were always collected at the same the same intervals. This showed that SMURF model was more effective in deep artificial reefs environment.

Overall results demonstrate that there is a difference in the recruit communities in Mid-water and Bottom SMURFs, with the latter having high number of species than the former. In your study developing the model SMURF, Ammann (2004) showed that SMURFS positioned at the bottom had similar abundances from those deployed in Mid-water.

Depth apparently did not have any influence in number of fish recruits per FAD, excluding the ARMs, where the few sampled fishes were found in devices placed on the bottom. FADs positioned closer to the bottom tend to aggregate similar total numbers of recruits, while significant differences between the samples usually occur between FADs positioned close the bottom to those from subsurface (Leis et al., 2002; Ammann, 2004), the latter tend to be preferred in studies focusing on only one species or in groups of similar 
species in view its high aggregation rates for these species (e.g. Ben-David \& Kritzer, 2005; Caselle et al., 2010). Our long-term experiments (Phase 2) were able to validate those of Phase 1 showing similar sampling rates around 3 recruits per SMURF.

The differences between positioning of FADs are more evident when analyzing species by species data due to their behavioral and biological characteristics that may or might not have preference for certain depths (Leis et al., 2002; Ammann, 2004). Analyses already performed showed that there is a difference between the recruits ' assemblages between the depths evaluated in this study (Correia et al., in preparation). These intrinsic characteristics of the species may also have influenced the similarity of samplings by immersion time.

Although most studies use two weeks as standard immersion time to sample fish recruits (for example Luzier \& Wilson Jr., 2004; Caselle et al., 2010; Klein et al., 2018; Ottman et al., 2017, 2018, 2019), some studies performed daily sampling (Valles et al., 2006) to more than two months of immersion time (Shima et al., 2012). This variation of sampling intervals often obeys the ecological and biological characteristics inherent to the species something already noted in literature (Ammann, 2004; Vallès et al., 2006). Here, two weeks were not responsible for higher samples numbers although were the immersion time most tested. Probably, the uninfluenced fish recruits' samplings by SMURF's Immersion time showed here reflect a pool of different species recruitment times that could only be tested species by species

The size of individuals sampled were according to the lengths found in several studies that used FADs for recruitment and smaller than the maximum recruitment size of $6 \mathrm{~cm}$ in reef fishes (Victor, 1991), indicating that the fishes sampled in our study were mostly newly settlers and young juveniles although we collected a couple of adults individuals from a small species (Correia et al., in preparation). The differences found by depths in the size ranges also show intrinsic characteristics of the species since some settle on FADs with higher sizes than the averages found in reef fish (Ben-David \& Kritzer, 2005).

When developing study with FADs it should be considered wave, currents and forces related to the structure (Özgül et al., 2011). Our pool experiments with local marine currents relation could prove that mid-water FADs remained less than $0.5 \mathrm{~m}$ from the planned depths. Thus, the abundance data obtained for this position did not have influence by bottom FADs. This concern should be taken into consideration in experiments that use FADs held suspended by mid-water buoys (e.g. Leis et al., 2002; Ammann, 2004; Paiva et al., 2015).

\section{FINAL CONSIDERATIONS}

The study of fish at great depths is challenging in itself, coupled with this, practices involving the positioning of specific structures on the seabed make research even more difficult for scientific divers. Therefore, we strongly recommend for further studies with FADs at those depths to always consider use of cables and weights to deploy and collect such structures avoiding unnecessary efforts from divers on the field work.

Finally, the present research shows that the FADs, more specifically the SMURFs, can serve as useful tools to study fish recruits and small species in artificial environments such as shipwrecks, both difficult to be perceived at visual censuses. It represents an efficient alternative strategy for ecological research of fish early stages. 
Acknowledgements - We thank to Coordenação de Aperfeiçoamento de Pessoal de Nível Superior (Capes) for primary author's scholarship and to Conselho Nacional de Desenvolvimento Científico e Tecnológico (CNPq) for Araújo, M.E. researcher grant $\mathrm{n}^{\mathrm{o}}$ 309984/2016-5. We also thank to Pró-Reitoria de Pesquisa e Pós-Graduação of UFPE (Propesq-UFPE) for undergrad scholarship, and to Idea Wild for donation of scientific underwater equipment. Authors want to thank to undergrads students Demétrio Câmara for FADs construction improvement and Guilherme França for field and laboratory helping, to the laboratory fellows and also great divers Walter Dennis, Cláudio Macêdo, Felipe Bastos, Vinicius Santos, Daniel Lippi for underwater sampling help. We thank Bruno da Silva for aquatic and boat operations helping. This project was done with help of Jedivers Diving Center, and the diving instructors Rafael Cunha and Marcelo Marenga. All samples were collected under environmental licenses SISBIO n ${ }^{0} 55133-1$, issued on 29/9/2016 and $\mathrm{n}^{\mathrm{o}} 55133-2$, issued on $2 / 10 / 2017$.

\section{REFERENCES}

Alevizon, W.S. \& Gorham, J.C. Effects of artificial reef deployment on nearby resident fishes. Bull. Mar. Sci., v. 44, n. 2, p. 646-661, 1989.

Ammann, A.J. SMURFs: standard monitoring units for the recruitment of temperate reef fishes. J. Exp. Mar. Biol. Ecol., v. 299, n. 2, p. 135-154, 2004.

Arney, R.N.; Froehlich, C.Y.M. \& Kline, R.J. Recruitment patterns of juvenile fish at an artificial reef area in the Gulf of Mexico. Mar. Coast. Fish., v. 9, n. 1, p. 79-92, 2017.

Baetscher, D.S.; Anderson, E.C.; Gilbert-Horvath, E.A.; Malone, D.P.; Saarman, E.T.; Carr, M.H. \& Garza, J.C. Dispersal of a nearshore marine fish connects marine reserves and adjacent fished areas along an open coast. Mol. Ecol., v. 28, n. 7, p. 1611-1623, 2019.

Ben-David, J. \& Kritzer, J.P. Early life history and settlement of the slender filefish, Monacanthus tuckeri (Monacanthidae), at Calabash Caye, Turneffe Atoll, Belize. Environ. Biol. Fishes, v. 73, n. 3, p. 275-282, 2005.

Bergstrom, M. Review of experiences with and present knowledge about fish aggregating devices. Bay of Bengal Programme, Development of Small-Scale Fisheries. FAO report BOBP/ WP/23, 57 p., Madras,1983.

Caselle, J.E.; Kinlan, B.P. \& Warner, R.R. Temporal and spatial scales of influence on nearshore fish settlement in the Southern California Bight. Bull. Mar. Sci., v. 86, n. 2, p. 355$385,2010$.

Caselle, J.E. \& Warner, R.R. Variability in recruitment of coral reef fishes: the importance of habitat at two spatial scales. Ecology, v. 77, n. 8, p. 2488-2504, 1996.

Correia, J.R.M.B.; Barros, M.J.G.; Cardoso, Á.T.P.; Lippi, D.L.; Câmara, D.L.F. \& Maranhão, H.A. Naufrágios e os peixes a eles associados, p. 319-344, in Araújo, M.E.; Feitosa, C.V. \& Mattos, S.M.G. (eds.). Ecologia de peixes recifais em Pernambuco. Recife, Brasil: Editora UFPE, p. 319-344, 2018.

Crean, A.J.; Swearer, S.E. \& Patterson, H.M. Larval supply is a good predictor of recruitment in endemic but not non-endemic fish populations at a high latitude coral reef. Coral Reefs, v. 29, n. 1, p. 137-143, 2010. 
Dempster, T. \& Taquet, M. Fish aggregation device (FAD) research: gaps in current knowledge and future directions for ecological studies. Rev. Fish Biol. Fish., v. 14, n. 1, p. 21-42, 2004.

Deudero, S.; Merella, P.; Morales-Nin, B.; Massutí, E. \& Alemany, F. Fish communities associated with FADs. Sci. Mar., v. 63, n. 3-4 p. 199-207, 1999.

Francois, S. Two examples of artificial floating reefs in Japan, p. 314-339, in Proceedings Symposium on Artificial Reefs and Fish Aggregating Devices as Tools for the Management and Enhancement of Marine Fishery Resources, 435 p., Colombo, 1991.

Galea, J.A. The 'Kannizzati' fishery, p. 85-91, in Proceedings and Technical Papers General Fisheries Council for the Mediterranean, 378 p., Rome, 1961.

Gooding, R.M. \& Magnuson, J.J. Ecological Significance of a Drifting Object to Pelagic Fishes. Pac. Sci., v. 21, n. 4, p. 486-497, 1967.

Haggarty, D.R.; Lotterhos, K.E. \& Shurin, J.B. Young-of-the-year recruitment does not predict the abundance of older age classes in black rockfish in Barkley Sound, British Columbia, Canada. Mar. Ecol. Prog. Ser., v. 574, p. 113-126, 2017.

Hunter, J.R. \& Mitchell, C.T. Association of fishes with flotsam in the offshore waters of Central America. Fish. Bull., v. 66, n. 1, p. 13-17, 1967.

Ibrahim, S.; Ambak, M.A.; Shamsudin, L. \& Samsudin, M.Z. Importance of fish aggregating devices (FADs) as substrates for food organisms of fish. Fish. Res., v. 27, n. 4, p. 265-273, 1996.

Jones, C.L.; Anderson, T.W. \& Edwards, M.S. Evaluating eelgrass site quality by the settlement, performance, and survival of a marine fish. J. Exp. Mar. Biol. Ecol., v. 445, p. 61-68, 2013.

Jones, G.P. The Importance of recruitment to the dynamics of a coral reef fish population. Ecology, v. 71, n. 5, p. 1691-1698, 1990.

Jones, M.K. \& Mulligan, T. Juvenile rockfish recruitment in Trinidad Bay, California. Trans. Am. Fish. Soc., v. 143, n. 2, p. 543-551, 2014.

Klein, M. Recruitment patterns and processes of coastal fish species in a temperate rocky reef. $\mathrm{PhD}$ Thesis, Universidade do Algarve, Faro, Portugal, 2016.

Klein, M.; Beveren, E.V.; Rodrigues, D.; Serrão, E.A.; Caselle, J.E.; Gonçalves, E.J. \& Borges, R. Small scale temporal patterns of recruitment and hatching of Atlantic horse mackerel (L.) at a nearshore reef area. Fish. Oceanogr., v. 27, n. 6, p. 505-516, 2018.

Kohn, Y.Y. \& Clements, K.D. Pelagic larval duration and population connectivity in New Zealand triplefin fishes (Tripterygiidae). Environ. Biol. Fishes, v. 91, n. 3, p. 275-286, 2011.

Leis, J.M.; Carson-Ewart, B.M. \& Webley, J. Settlement behaviour of coral-reef fish larvae at subsurface artificial-reef moorings. Mar. Freshwater. Res., v. 53, n. 2, p. 319-327, 2002.

Lewis, R.A. Recruitment and post-recruit immigration affect the local population size of coral reef fishes. Coral Reefs, v. 16, n. 3, p. 139-149, 1997.

Lotterhos, K.E. \& Markel, R.W. Oceanographic drivers of offspring abundance may increase or decrease reproductive variance in a temperate marine fish. Mol. Ecol., v. 21, n. 20, p. 5009-5026, 2012. 
Luzier, C.W. \& Wilson Jr., R.R. Analysis of mtDNA haplotypes of kelp bass tests for siblingdominated recruitment near marine protected areas of the California Channel Islands. Mar. Ecol. Prog. Ser., v. 277, p. 221-230, 2004.

Miller, S.; Vallès, H. \& Oxenford, H.A. Preliminary analysis of reef fish settlement patterns in Eleuthera, The Bahamas, p. 234-235, in Proceedings of the 66th Gulf and Caribbean Fisheries Institute, Corpus Christi, Texas, 2014.

Morales-Nin, B.; Cannizzaro, L.; Massuti, E.; Potoschi, A. \& Andaloro, F. An overview of the FADs fishery in the Mediterranean Sea, p. 184-207, in Le Gall, J.-Y.; Cayre, P. \& Taquet, M. (eds.). Pêche thoniere et dispositifs de concentration de poisons. Ed. Ifremer, Actes Colloq, Trois-Îlets, p. 184-207, 2000.

Morton, D.N. \& Shima, J.S. Habitat configuration and availability influences the settlement of temperate reef fishes (Tripterygiidae). J. Exp. Mar. Biol. Ecol., v. 449, p. 215-220, 2013.

Murdy, E.O. The commercial harvesting of tuna attracting payaos: a possible boon for small-scale fishermen. ICLARM Newslett., v. 1, p. 10-12, 1980.

National Research Council Artificial Reefs and Fish Aggregating Devices, p. 85-114, in National Research Council (eds.), Fisheries technologies for developing countries. The National Academies Press, Washington, DC, p. 85-114, 1988.

Ottmann, D.; Grorud-Colvert, K.; Huntington, B. \& Sponaugle, S. Interannual and regional variability in settlement of groundfishes to protected and fished nearshore waters of Oregon, USA. Mar. Ecol. Prog. Ser., v. 598, p. 131-145, 2018.

Ottmann, D.; Grorud-Colvert, K.; Sard, N.M.; Huntington, B.E.; Banks, M.A. \& Sponaugle, S. Long-term aggregation of larval fish siblings during dispersal along an open coast. Proc. Natl. Acad. Sci. USA, v. 113, n. 49, p. 14067-14072, 2016.

Ottmann, D.; Grorud-Colvert, K. \& Sponaugle, S. Age and growth of recently settled splitnose and redbanded rockfishes in the northern California Current. J. Sea Res., v. 148149, p. 8-11, 2019.

Özgül, A.; Lök, A. \& Düzbastilar, F.O. Two experimental fish aggregating systems (fads) in the Aegean Sea: their design and application. Braz. J. Oceanogr., v. 59, p. 13-19, 2011.

Paiva, M.I.G.; Mendes, L.F.; Lins-Oliveira, J.E.; Alencar, C.E.R.D. \& Torquato, F.O. Temporal and spatial patterns on the settlement of reef fish larvae in a South Atlantic reef, Bahia, Brazil. Pan-Am. J. Aquat. Sci., v. 10, p. 19-28, 2015.

Santos, D.C.; Hazin, F.V.; Fisher, A.F.; Feitosa, F.N. \& Araújo, M.E. The creation of a shipwreck park off the coast of Pernambuco, Brazil. Rev. Bras. Eng. Pesca, v. 3, n. 1, p. 91-97, 2008.

Santos, D.H.C.; Silva-Cunha, M.G.G.; Santiago, M.F. \& Passavante, J.Z.O. Characterization of phytoplankton biodiversity in tropical shipwrecks off the coast of Pernambuco, Brazil. Acta Bot. Bras., v. 24, p. 924-934, 2010.

Schettini, C.A.F.; Domingues, E.D.C.; Truccolo, E.C.; Oliveira Filho, J.C.D. \& Mazzini, P.L.F. Seasonal variability of water masses and currents at the eastern Brazilian continental shelf (7.5 -9o S). Reg. Stud. Mar. Sci., v. 16, n. Supplement C, p. 131-144, 2017.

Schettini, C.A.F.; Truccolo, E.C.; Domingues, E.D.C. \& Salles, A.M. Plataforma continental: características meteo-oceanográficas, p. 164-176, in Araújo, M.E.; Feitosa, 
C.V. \& Mattos, S.M.G. (eds.). Ecologia de peixes recifais em Pernambuco. Recife, Brasil: Editora UFPE, p. 164-176, 2018.

Schroeder, R.E. Effects of patch reef size and isolation on coral reef fish recruitment. Bull. Mar. Sci., v. 41, n. 2, p. 441-451, 1987.

Selkoe, K.A.; Gaines, S.D.; Caselle, J.E. \& Warner, R.R. Current shifts and kin aggregation explain genetic patchiness in fish recruits. Ecology, v. 87, n. 12, p. 3082-3094, 2006.

Shima, J.S.; Mcnaughtan, D.; Geange, S.W. \& Wilkinson, S. Ontogenetic variation in site fidelity and homing behaviour of a temperate reef fish. J. Exp. Mar. Biol. Ecol., v. 416-417, p. 162-167, 2012.

Shima, J.S. \& Swearer, S.E. Spatially variable larval histories may shape recruitment rates of a temperate reef fish. Mar. Ecol. Prog. Ser., v. 394, p. 223-229, 2009.

Shulman, M.J. Recruitment of coral reef fishes: effects of distribution of predators and shelter. Ecology, v. 66, n. 3, p. 1056-1066, 1985.

Shulman, M.J. \& Ogden, J.C. What controls tropical reef fish populations: recruitment or benthic mortality? An example in the Caribbean reef fish Haemulon flavolineatum. Mar. Ecol. Prog. Ser., v. 39, p. 233-242, 1987.

Shulman, M.J.; Ogden, J.C.; Ebersole, J.P.; Mcfarland, W.N.; Miller, S.L. \& Wolf, N.G. Priority effects in the recruitment of juvenile coral reef fishes. Ecology, v. 64, n. 6, p. 1508-1513, 1983.

Siddon, E.C.; Siddon, C.E. \& Stekoll, M.S. Community level effects of Nereocystis luetkeana in southeastern Alaska. J. Exp. Mar. Biol. Ecol., v. 361, n. 1, p. 8-15, 2008.

Soemarto. Fish behaviour with special reference to pelagic shoaling species: Lajang (Decapterus spp.), p. 89-93, in 8th Proceedings Indo-Pacific Fisheries Council., Colombo, Ceylon, 1960.

Steele, M.A.; Malone, J.C.; Findlay, A.M.; Carr, M.H. \& Forrester, G.E. A simple method for estimating larval supply in reef fishes and a preliminary test of population limitation by larval delivery in the kelp bass Paralabrax clathratus. Mar. Ecol. Prog. Ser., v. 235, p. 195-203, 2002.

Stephens, J.; Wendt, D.; Wilson-Vandenberg, D.; Carroll, J.; Nakamura, R.; Nakada, E.; Rienecke, S. \& Wilson, J. Rockfish resources of the South Central California coast: analysis of the resource from partyboat data, 1980-2005. CalCOFI Rep., v. 47, p. 140-155, 2006.

Tavernetti, R.; Morgan, S. \& Yu, Q. Effect of biological fouling on passive collectors used to estimate fish recruitment. J. Fish Biol., v. 75, n. 3, p. 699-706, 2009.

Vallès, H.; Hunte, W. \& Kramer, D.L. Variable temporal relationships between environment and recruitment in coral reef fishes. Mar. Ecol. Prog. Ser., v. 379, p. 225-240, 2009.

Valles, H.; Kramer, D.L. \& Hunte, W. A standard unit for monitoring recruitment of fishes to coral reef rubble. J. Exp. Mar. Biol. Ecol., v. 336, n. 2, p. 171-183, 2006.

Vallès, H.; Kramer, D.L. \& Hunte, W. Temporal and spatial patterns in the recruitment of coral-reef fishes in Barbados. Mar. Ecol. Prog. Ser., v. 363, p. 257-272, 2008.

Victor, B.C. Settlement strategies and biogeography of reef fishes, p. 231-260, in Sale, P.F. (eds.). The ecology of fishes on coral reefs. San Diego: Academic Press, p. 231-260, 1991. 
Walsh, W.J. Reef fish community dynamics on small artificial reefs: the influence of isolation, habitat structure, and biogeography. Bull. Mar. Sci., v. 36, n. 2, p. 357-376, 1985.

White, J.W. \& Caselle, J.E. Scale-dependent changes in the importance of larval supply and habitat to abundance of a reef fish. Ecology, v. 89, n. 5, p. 1323-1333, 2008. 